\title{
EXPERIMENTAL INVESTIGATION OF COMPRESSIVE STRENGTH OF CONCRETE BY PARTIAL REPLACEMENT OF CONSTITUENTS
}

\author{
Durgalakshmi.K.M ${ }^{1}$, Krishnachandran.V.N² \\ ${ }^{1}$ Department of Civil Engineering, Kerala Technological University, Palakkad, Kerala \\ ${ }^{2}$ Department of Civil Engineering, Kerala Technological University, Palakkad, Kerala
}

\begin{abstract}
Undoubtedly concrete is the most versatile and widely used construction material. It is the material of choice with strength, performance and durability. This study aims at utilization and to ascertain the suitability of saw dust ash as a partial replacement of cement, glass powder as a partial replacement of fine aggregate and rubber tyre pieces as a partial replacement of coarse aggregate in normal M30 grade concrete. Initially, all trial combinations were casted by replacing binder, fine aggregate and coarse aggregate at a varying rate of 2 to $10 \%$. The replacement percentage of binder giving maximum strength is chosen and is fixed accordingly for further studies. Thereafter, the percentage of coarse aggregate and fine aggregate were changed from 2 to $8 \%$ to arrive at an optimum mix having maximum compressive strength. The strength performance of these concrete with normal concrete mix is investigated and findings are reported.
\end{abstract}

Keywords - Rubber Tyre Pieces, Saw Dust Ash, Waste- Glass Powder ****

\section{INTRODUCTION}

Concrete is by far the most versatile and most widely used construction material worldwide. It can be engineered to satisfy a wide range of performance specifications, unlike other building materials, such as natural stone or steel, which generally have to be used as they are.The properties of concrete depend not only on the various constituent materials but also on the way they are proportioned and mixed, as well as on the methods of placing and curing the composite.

Waste recycling can provide an opportunity to collect and dispose it in an environmental and economical way and it can be also converted into a resource. The utilization of industrial waste or secondary materials has encouraged the production of cement and concrete in construction field. Over recent decades, intensive research studies have been carried out to explore all possible reuse methods. Further investigations are needed to clarify for instance which are the possibilities and means to maximize concrete performance.

\section{METHODOLOGY}

The work is done with the following process:-

- Collection of materials

Basic materials such as cement, sand, and gravel required for the concrete are to be collected. Cement used in the work was PPC (Portland Pozzolana Cement). Fineaggregate used was $\mathrm{M}$ sand and coarse aggregate used was natural gravel. Also the waste materials such as saw dust, waste glass and waste rubber tyre required for the work were collected from different sources.

- $\quad$ Recycling (preparation) of waste materials

The collected waste materials were recycled into convenient form required for the work.
- Material testing

The basic tests for all the materials were carried out and it was done for recycled waste materials also.

- Mix design

After the obtained result from material testing, mix design was carried out.

Control mix design and casting was carried out.

- Casting of samples

Required numbers of cubes samples were casted and cured properly.

- $\quad$ Testing of samples

Compressive strength and light weight character were tested.

- Interpretation of results

\subsection{Material Collection and Preparation}

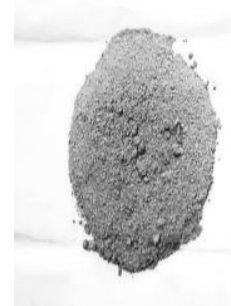

(a)Saw Dust

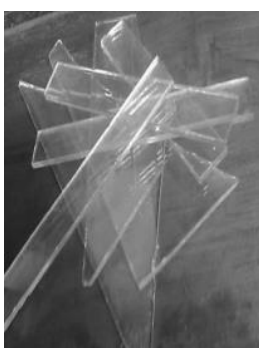

(b) Waste Glass

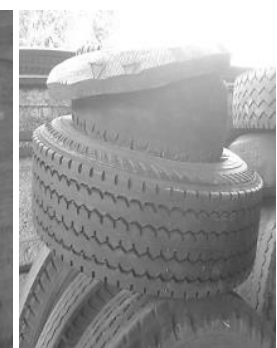

(c) Rubber Tyre
Fig.1

Saw dust used in this project which was obtained from nearby timber milling factory is air-dried and then calcinated 
into ashes by burning process. The saw dust ash was sieved through $150 \mu$ and those passing the sieve were used for this work.

Glass powder is used as a substitute material for sand in concrete. Before adding in the concrete, the glass was powdered to desired size. It was crushed using Compression Testing Machine and then sieved through $1.18 \mathrm{~mm}$ IS sieve.

Rubber aggregate is prepared by manual cutting and sieved through $20 \mathrm{~mm}$ IS sieve. The reason for it is that they can give the required shape and size which is similar to the common natural gravel.
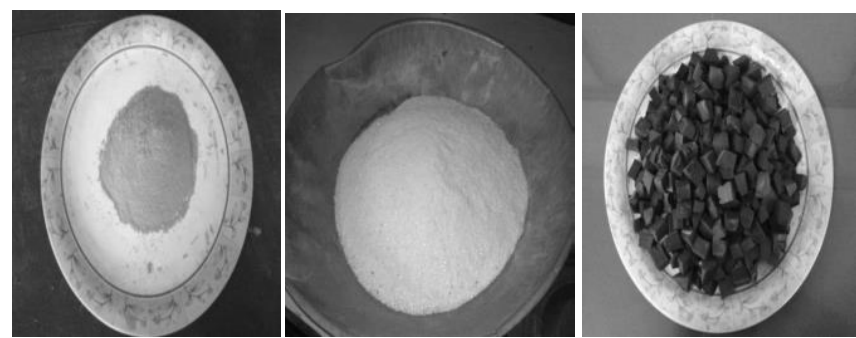

(a)Saw Dust Ash (b) Glass Powder (c) Rubber Tyre Pieces

Fig.2

\subsection{Material Testing}

The relevant tests to identify the properties of the aggregates were carried out manually.

The properties of all the materials were tested in the laboratory to check whether the sample can be used in the production of concrete. The result obtained from the laboratory is compared with the conventional materials.

Table -1 Material Testing Results comparison with Cement and Saw Dust Ash

\begin{tabular}{|c|c|c|c|}
\hline $\begin{array}{l}\text { Material } \\
\text { Properties }\end{array}$ & $\begin{array}{l}\text { Results } \\
\text { (Cement) }\end{array}$ & $\begin{array}{l}\text { Results } \\
\text { (SDA) }\end{array}$ & $\begin{array}{l}\text { Permissible } \\
\text { Limit } \\
\text { According } \\
\text { to IS 1489: } \\
1991\end{array}$ \\
\hline Fineness & $1.7 \%$ & $5 \%$ & $5 \%$ \\
\hline Specific & 2.85 & 2.71 & Around 2.9 \\
\hline Gravity & & & \\
\hline Standard & $32 \%$ & & \\
\hline Consistency & & & Not \\
\hline Initial & $90 \mathrm{~min}$ & & 30mins \\
\hline Setting Time & & & \\
\hline Soundness & $1 \mathrm{~mm}$ & & Not $>16 \mathrm{~mm}$ \\
\hline Compressive & & & \\
\hline Strength & $20.7 \mathrm{~N} / \mathrm{mm}^{2}$ & & $22 \mathrm{~N} / \mathrm{mm}^{2}$ \\
\hline
\end{tabular}

Table -2: Material Testing Results comparison with Coarse Aggregate and Rubber Tyre Pieces

\begin{tabular}{|l|l|l|l|}
\hline $\begin{array}{l}\text { Material } \\
\text { Properties }\end{array}$ & $\begin{array}{l}\text { Results } \\
\text { (Cement) }\end{array}$ & $\begin{array}{l}\text { Results } \\
\text { (SDA) }\end{array}$ & $\begin{array}{l}\text { Permissible } \\
\text { Limit } \\
\text { According to } \\
\text { IS:383 1970 }\end{array}$ \\
\hline $\begin{array}{l}\text { Bulk } \\
\text { Density } \\
\text { Void Ratio } \\
\text { Specific } \\
\text { Gravity } \\
\text { Water } \\
\text { Absorption }\end{array}$ & 1.662 & 0.674 & 1.52 to 1.68 \\
\hline
\end{tabular}

Table 3: Material Testing Results comparison with Fine

\begin{tabular}{|c|c|c|c|}
\hline \multicolumn{4}{|c|}{ Aggregate and Glass Powder } \\
\hline $\begin{array}{l}\text { Material } \\
\text { Properties }\end{array}$ & $\begin{array}{l}\text { Results } \\
\text { (Cement) }\end{array}$ & $\begin{array}{l}\text { Results } \\
\text { (SDA) }\end{array}$ & $\begin{array}{l}\text { Permissible } \\
\text { Limit } \\
\text { According } \\
\text { to IS:383 } \\
1970\end{array}$ \\
\hline $\begin{array}{l}\text { Sieve } \\
\text { Analysis }\end{array}$ & Zone II & Zone II & \\
\hline Bulking & $\begin{array}{l}38.89 \% \text { (for } \\
8 \% \\
\text { moisture) }\end{array}$ & $\begin{array}{l}53.85 \% \\
\text { for } 8 \% \\
\text { moisture }\end{array}$ & $\begin{array}{l}10 \% \\
\text { moisture }\end{array}$ \\
\hline Bulk & 1.441 & 1.351 & $1.52-1.68$ \\
\hline Void Ratio & 0.846 & 0.574 & NOL $>1$ \\
\hline Specific & & & 2.5 to 2.9 \\
\hline Gravity & 2.66 & 2.13 & \\
\hline Water & & & Not $>4 \%$ \\
\hline Absorption & $2.6 \%$ & $1.6 \%$ & \\
\hline
\end{tabular}

\subsection{Mix Design}

By selecting the right mix proportion of concrete, the concrete workability can be achieved. The mix design was according to IS : 10262 - 1982 guidelines for M30 mix including replacements are designed for the investigation.

Table 4: Mix Design Results

\begin{tabular}{|l|l|}
\hline Design Parameters & Results for M30 \\
\hline Target mean strength & $38.25 \mathrm{~N} / \mathrm{mm}^{2}$ \\
\hline Water cement Ratio & 0.45 \\
\hline Water Content & 186 litres \\
\hline Cement Content & $413.333 \mathrm{~kg} / \mathrm{m}^{3}$ \\
\hline Fine aggregate content & $604.283 \mathrm{~kg} / \mathrm{m}^{3}$ \\
\hline Coarse aggregate content & $1235.9 \mathrm{~kg} / \mathrm{m}^{3}$ \\
\hline Mix Ratio & $1: 1.46: 2.99$ \\
\hline
\end{tabular}

\subsection{Casting}

The cubes are of size $15 \times 15 \times 15 \mathrm{~cm}$ were casted by replacing cement, fine aggregate and coarse aggregate with saw dust ash, glass powder and rubber tyre pieces respectively by $2,4,6,8$ and $10 \%$ to fix the maximum replaceable percentage. 


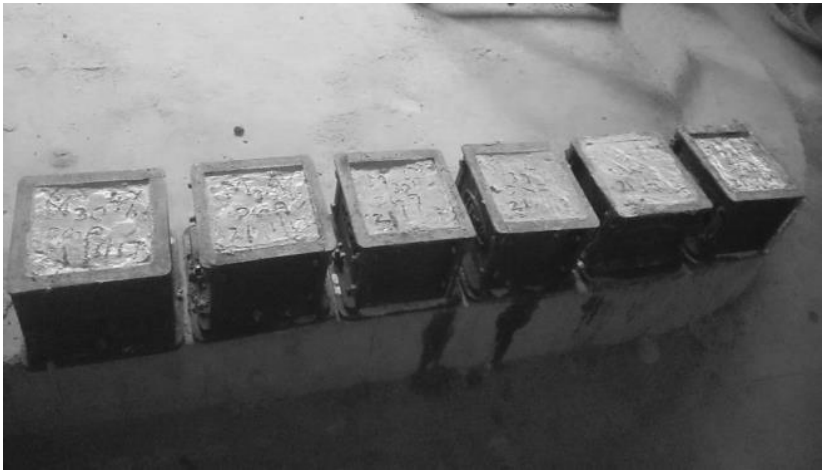

Fig.3 Cube Specimens

\subsection{Testing}

Compressive strength and light weight character of all the samples was determined after curing of 7days. Light weight character was measured for concrete before curing itself. The average dry weight of concrete cube specimens containing replacement was compared with average dry weight of normal M30 concrete cube specimens and the percentage decrease in dry weight was measured.

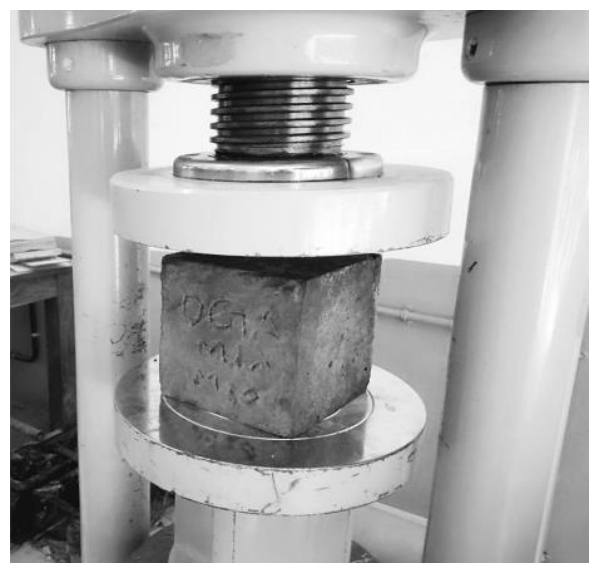

Fig.4 Compressive Strength Test Set up

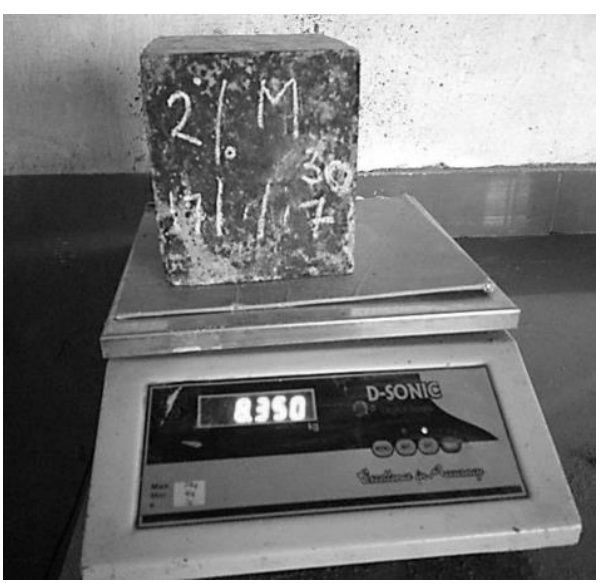

Fig.5 Measuring of weight

After the initial test results maximum replaceable percentage was obtained and it is chosen as the replacement percentage for binder for further trials. Then samples were casted with coarse aggregate and fine aggregate percentages were changed from 2 to $8 \%$.

\section{RESULTS}

The compressive strength for initial trials was obtained as increasing up to a replacement of $4 \%$ and then decreasing.

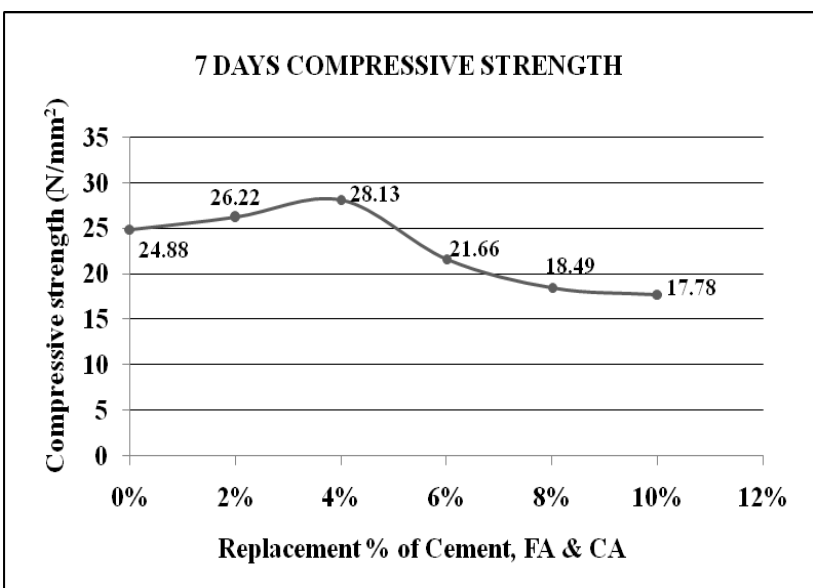

Fig.6 Seven Days Compressive Strength without varying aggregate content

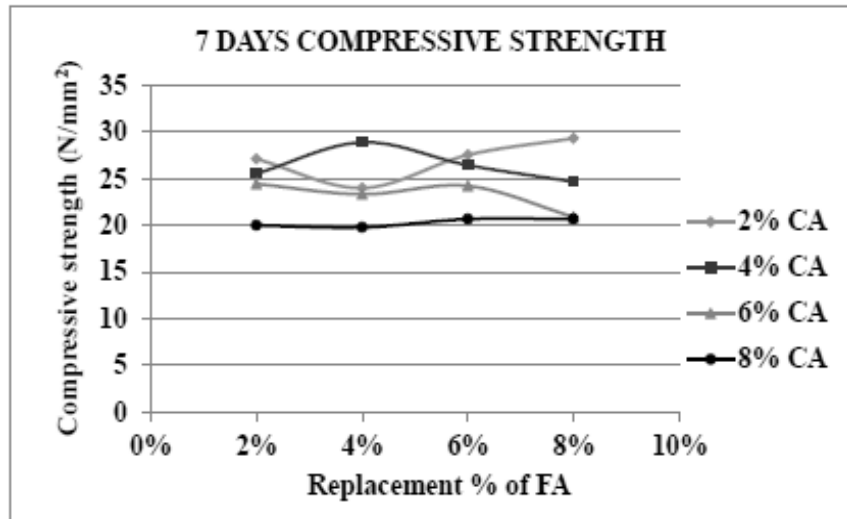

Fig.7 Seven Days Compressive Strength without varying aggregate content

The $\%$ decrease in weight for initial trials was obtained as decreasing from $0 \%$ to $10 \%$ of replacement.

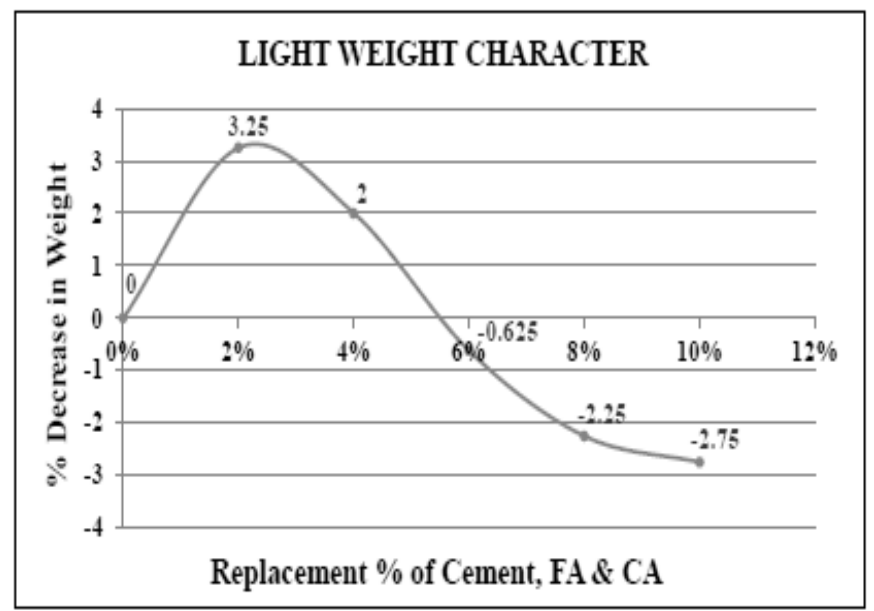

Fig.8 Light Weight Character without varying aggregate content 


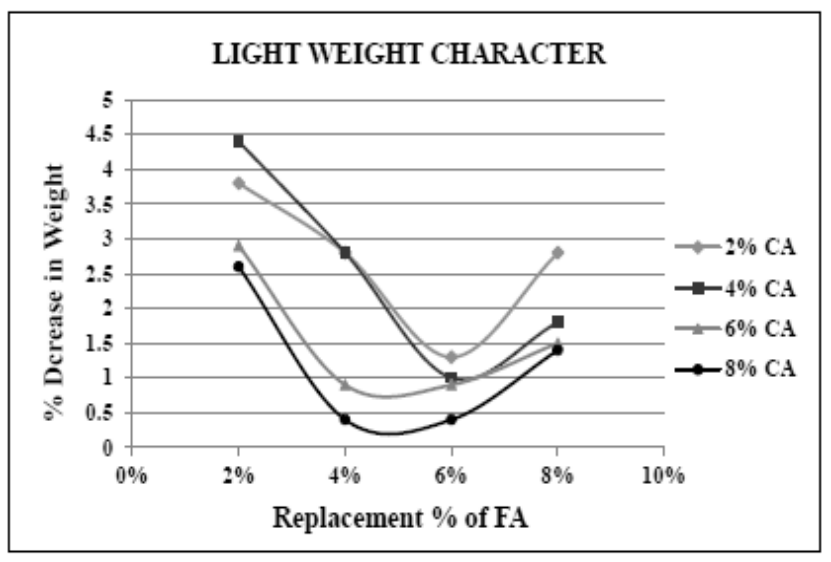

Fig.9: Light Weight Character with varying Aggregate Content

\section{DISCUSSION}

From the initial trial combinations by replacing binder, fine aggregate and coarse aggregate at a rate of 2 to $10 \%$, maximum compressive strength was obtained for a replacement of $4 \%$. The significant increase in strength of concrete can be due to the pozzolanic reaction of Saw Dust Ash and the cementitious products formed as a result of hydration of cement. Compressive strength was found to increase with the addition of waste glass powder due to the angular nature of the glass particles facilitating increased bonding with the cement paste.

In case of compressive strength a maximum value was obtained at a replacement of cement with $4 \%$ SDA, FA with $8 \%$ glass powder and $\mathrm{CA}$ with $2 \%$ rubber tyre pieces. The minimum percentage of rubber tyre pieces will not affect the bonding of concrete mix and also provide minimum voids and vacuum in the matrix. Along with this, the maximum percentage of glass powder increases the bonding by the angular structure of its particle and hence strength will also be enhanced. Waste glass contain high silica content $\left(\mathrm{SiO}_{2}\right)$ i.e. $72 \%$ and high compressive strength. Waste glass powder also reacts with alkalis in cement (pozzolanic reaction) and cementitious product that help contribute to the strength development.

\section{CONCLUSION}

By fixing the percentage of replacing binder at $4 \%$ and then varying the replacement percentage of fine aggregate and coarse aggregate from 2 to $8 \%$, an optimum mix ratio with a maximum strength was obtained as $4: 8: 2$, viz. with a replacement of cement with $4 \%$ of SDA, fine aggregate with $8 \%$ of glass powder and coarse aggregate with $2 \%$ of rubber tire pieces. This appears to be a best mix for achieving maximum strength for M30 grade concrete.

\section{REFERENCES}

[1]. Bhupendra Singh Shekhawat and Dr. Vanita Aggarwal (2014) Utilisation of Waste Glass Powder in Concrete - A Literature Review, International Journal of Innovative Research in Science, Engineering and Technology, 3, 1482214826
[2]. Deepak Parakh et.al (2016) Partial Replacement of Coarse Aggregate by Waste Tyre Rubber and Fine Aggregate by Waste Glass, Imperial Journal of Interdisciplinary Research, 2, 1119-1123

[3]. Dr. G.Vijayakumar et.al (2013) Studies on Glass Powder as Partial Replacement of Cement in Concrete Production, International Journal of Emerging Technology and Advanced Engineering, 3, 153-157

[4]. Dr. M.Vijaya Sekhar Reddy et.al (2015) Incorporation of Waste Glass Powder as Partial Replacement of Fine Aggregate in Cement Concrete, International Journal of Scientific \& Engineering Research, 6, 405-409

[5]. Dr. T. Sekar et.al (2011) Studies on Strength Characteristics on Utilization of Waste Materials as Coarse Aggregate in Concrete, International Journal of Engineering Science and Technology, 3, 5436-5440

[6]. Egbe-Ngu Ntui Ogork and Solomon Ayuba (2014) Influence of Sawdust Ash (SDA) as Admixture in Cement Paste and Concrete, International Journal of Innovative Science, Engineering \& Technology, 1, 736-743

[7]. Felix F. Udoeyo and Philibus U. Dashibil (2002) Saw Dust Ash as Concrete Material, Journal of Materials in Civil Engineering, 14, 173-176

[8]. G. Nagesh Kumar et.al (2014) Using Tyres Wastes as Aggregates in Concrete to form Rubcrete - Mix for Engineering Applications, International Journal of Research in Engineering and Technology, 3, 500-509

[9]. G. Senthil Kumaran et.al (2008) A Review on Construction Technologies that Enables Environmental Protection: Rubberized Concrete, American Journal of Engineering and Applied Sciences, 1, 41-45

[10]. Johnny Bolden et.al (2013) Utilization of Recycled and Waste Materials in Various Construction Applications, American Journal of Environmental Science, 9, 14-24

[11]. Kamlesh Saini et.al (2016) Effect on strength properties of concrete by using waste wood powder as partial replacement of cement, International Journal of Civil Engineering, 3, 172-176

[12]. K.Charankumar and Dr. S. Siddi Raju (2015) Re-Use of Waste Tire Rubber Pieces in the Production of Light Weight Concrete, International Journal of Science and Research, 4, 1720-1724

[13]. K.Gopinath et.al (2015) Utilization of Saw Dust in Cement Mortar \& Cement Concrete, International Journal of Scientific \& Engineering Research, 6, 665-682

[14]. K.Madhangopal et.al (2014) Study the Influence of Waste Glass Powder on the Properties of Concrete, IOSR Journal of Mechanical and Civil Engineering, 11, 34-38

[15]. Kotresh K.M and Mesfin Getahun Belachew (2014) Study On Waste Tyre Rubber As Concrete Aggregates, International Journal of Scientific Engineering and Technology, 3, 433-436

[16]. M. Adaway and Y. Wang et.al (2015) Recycled glass as a partial replacement for fine aggregate in structural concrete - Effects on compressive strength, Electronic Journal of Structural Engineering, 14, 116-122

[17]. Melik Bekhiti et.al (2014) Properties of Waste Tire Rubber Powder, Engineering, Technology \& Applied Science Research, 4, 669-672 
[18]. M. Iqbal Malik et.al (2013) Study of Concrete Involving Use of Waste Glass as Partial Replacement of Fine Aggregates, IOSR Journal of Engineering, 3, 08-13

[19]. M.Mageswari and Dr. B.Vidivelli (2013) The Use of Sheet Glass Powder as Fine Aggregate Replacement in Concrete, Open Civil Engineering Journal, 4, 65-71

[20]. Mohammad Iqbal Malik et.al (2015) Partial Replacement of Cement by Saw Dust Ash in Concrete A Sustainable Approach, International Journal of Engineering Research and Development, 11, 48-53

[21]. Mr. Ankit J Patel et.al (2014) Literature Review on Different Waste Materials Use in Concrete, Journal of Emerging Technologies and Innovative Research, 1, 899-902

[22]. Mr Ankit J. Patel et.al (2014) Review on use of Waste Material in Concrete, International Journal For Technological Research In Engineering, 2, 307-310

[23]. N. F. Isa et.al (2014) The Use of Rubber Manufacturing Waste as Concrete Additive, Journal of Advanced Research in Applied Mechanics, 4, 12-18

[24]. Nitish Puri et.al (2013) Utilization of Recycled Wastes as Ingredients in Concrete Mix, International Journal of Innovative Technology and Exploring Engineering, 2, 74-78

[25]. Obilade I. O. (2014) Use of Saw Dust Ash as Partial Replacement for Cement In Concrete, International Journal of Engineering Science Invention, 3, 36-40

[26]. IS 1489 ( Part 1 ) : 1991 "Indian Standard Portland Pozzolana Cement Specification”, Bureau of Indian Standards (Third Revision), (First Reprint MARCH 1993), New Delhi 110002

[27]. IS : 383 - 1970 "Indian Standard Specification for Coarse and Fine Aggregates from Natural Sources for Concrete - ", Bureau of Indian Standards, (Second Revision), (Ninth Reprint SEPTEMBER 1993), New Delhi 110002

[28]. IS : 516 - 1959 "Indian Standard Methods of Tests for Strength of Concrete ", Bureau of Indian Standards, (Eighteenth Reprint JUNE 2006), New Delhi 110002

[29]. IS : 2386 ( Part I) - 1963 "Indian Standard Methods of Tests for Aggregates for Concrete - Particle Size and Shape ", Bureau of Indian Standards, (Eleventh Reprint AUGUST 1997), New Delhi 110002

[30]. IS : 2386 ( Part II) - 1963 "Indian Standard Methods of Tests for Aggregates for Concrete - Estimation of Deleterious Materials and Organic Impurities", Bureau of Indian Standards, (Eleventh Reprint SEPTEMBER 2006), New Delhi 110002

[31]. IS : 2386 ( Part III) - 1963 "Indian Standard Methods of Tests for Aggregates for Concrete - Specific Gravity, Density, Voids, Absorption and Bulking”, Bureau of Indian Standards, (Eighth Reprint MARCH 1997), New Delhi 110002

[32]. IS : 2386 ( Part IV) - 1963 "Indian Standard Methods of Tests for Aggregates for Concrete - Mechanical Properties", Bureau of Indian Standards, (Tenth Reprint MARCH 1997), New Delhi 110002

[33]. IS-456-2000 "Indian Standard Plain and Reinforced Concrete - Code of Practice", Bureau of Indian Standards (Fourth Revision), (Twelfth Reprint FEBRUARY 2010), New Delhi 110002

[34]. IS 10262 : 1982 "Indian Standard Recommended Guidelines For Concrete Mix Design", Bureau of Indian Standards, (Fifth Reprint MARCH 1988), New Delhi 110002
[35]. IS 10262 : 2009 "Indian Standard Concrete Mix Proportioning - Guidelines", Bureau of Indian Standards (First Revision), New Delhi 110002 